REFLEKSI HUKUM

Jurnal Ilmu Hukum
p-ISSN 2541-4984 | e-ISSN 2541-5417

Volume 4 Nomor 1, Oktober 2019, Halaman 41-60

DOI: https://doi.org/10.24246/jrh.2019.v4.i1.p41-60

Open access at: http://ejournal.uksw.edu/refleksihukum

Penerbit: Fakultas Hukum Universitas Kristen Satya Wacana

\title{
MENGGAGAS CITA MORAL DALAM PENAFSIRAN HUKUM HAKIM
}

\author{
Christina Maya Indah S. \\ Fakultas Hukum Universitas Kristen Satya Wacana \\ Korespodensi: mayauksw@yahoo.co.id
}

\begin{abstract}
Abstrak
Hakim dalam pelaksanaan tugasnya bukanlah semata sebagai mulut undang-undang (la bouche de la loi). Pekerjaan hakim adalah menafsirkan peristiwa hukum yang konkret dengan ketentuan hukum yang abtrak. Sejalan dengan pemahaman bahwa ilmu Hukum adalah sebuah eksemplar Hermeneutik in optima forma yang dipublikasikan pada aspek hukum kehidupan bermasyarakat, maka hakim dalam mengimplementasikan Ilmu Hukum untuk menyelesaikan suatu masalah hukum, melakukan kegiatan interpretasi yang tidak hanya dilakukan terhadap teks yuridis, melainkan juga terhadap kenyataan yang menimbulkan masalah hukum yang bersangkutan.Penafsiran hukum hakim yang bercita moral merupakan konsepsi dari law as interpretation/processes of interpreting, serta pada hukum sebagai nilai di mana dikonsepsikan Law as what ought to be in moral or ideal precepts. Artikel ini memberikan argumentasi bahwa membangun penafsiran hukum hakim berarti upaya melakukan pengembangan Ilmu Hukum hakim melalui pendekatan dinamis hermeneutika hukum yang mengakomodasi cita hukum dalam penafsiran hakim yang "open mindedness"dan bermuatan humanistik dalam perspektif moral.
\end{abstract}

Kata Kunci: Hakim; Penafsiran; Moral.

\begin{abstract}
In implementing his duty, a judge shall not only be considered as the mouth of acts (la bouche de la loi). The duty of judge is also to interpret law facts in concreto with abstract regulations. It has to be noted that jurisprudence is a hermeneutic exemplar in optima forma which is internalized in law of society. Accordingly, judge may not only interpret the juridical text, but also interpret the fact that results legal problems in order to solve the legal problems. The interpretation of the judge which contains the idea of moral is a concept of law as interpretation/processes of interpreting and also a concept of law as a value based on a statement of 'law as what ought to be in moral or ideal precepts'. This article argues that building the judge's legal interpretation means developing judge jurisprudence using the dynamic approach in legal hermeneutics. Such approach accomodates the ideal of law in judge's interpretation that includes open-mindedness and humanistic in moral perspective.
\end{abstract}

\section{Keywords: Judge; Interpretation; Moral.}




\section{PENDAHULUAN}

Penafsiran hakim selalu berada dalam suatu penafsiran atas teks, konteks, dan kontekstualisasi. Penafsiran hakim atau interpretasi hakim akan lebih terpahami dalam kajian hermeneutika yang berupaya membangun kerangka penafsiran/tradisi mindset kultur hakim. Dibutuhkan suatu pemikiran pemaknaan akan penafsiran yang 'open mindedness' bermuatan humanistik dalam perspektif moral. Dalam pekerjaan penafsiran hukum, hakim membutuhkan suatu analisis untuk me-review kajian normatif yang disorotkan pada faktafakta faktual dan merumuskannya dalam hubungan sebab akibat. Hakim dalam pengadilan akan melakukan interpretasi tentang makna bahasa yang abstrak/in abstracto dari perundangundangan terhadap kasus-kasus yang ada yang diperhadapkan pada hukum, dan juga hakim harus menafsirkan bahasa moral/moral reading yang tersimpan 'dalam bahasa perundangundangan, atau bisa jadi hakim akan menafsirkan bahasa yang abstrak namun muncul dari etika refleksi sosial yang ideal dari masyarakat dan disorotkan pada kasus-kasus.

Oleh karenanya, dalam praktek peradilan, hakim bukan hanya sekedar sebagai corong atau terompet undangundang (UU) atau sebagai la bouche de la loi saja, melainkan hakim harus melakukan interpretasi. Dalam pemikiran legisme, hakim hanya berbuat untuk menerapkan UU secara tegas, karena UU dianggap sudah lengkap, jelas dan benar. Ada pendapat yang mengatakan bahwa interpretasi terhadap teks perundang-undangan diperlukan hanya apabila dirasakan bahwa ketentuan perundang-undangan dirasa sudah tidak sesuai lagi dengan perkembangan kebutuhan hukum dan tidak sesuai dengan rasa keadilan.

Hakim tingkat pertama dan hakim tingkat banding sebagai judex facti dan hakim agung sebagai judex juris memiliki tugas untuk memeriksa dan memutus atau mengadili perkara berdasarkan hukum yang berlaku dan juga berdasarkan keyakinan hakim. Bagir Manan menyatakan bahwa rumusan UU yang bersifat umum tidak pernah menampung secara pasti setiap peristiwa hukum. Hakimlah yang berperan menghubungkan atau menyambungkan peristiwa hukum yang kongkrit dengan ketentuan hukum yang abstrak. Sudah menjadi pekerjaan sehari-hari hakim memberikan penafsiran atau konstruksi suatu ketentuan hukum dengan suatu peristiwa konkret. ${ }^{1}$ Oleh karenanya jelas, bahwa penafsiran hukum itu hal yang harus dilakukan hakim manakala diperhadapkan untuk memutuskan suatu kasus.

Tulisan ini mengkaji alasan bagi hakim dalam melakukan interpretasi harus menggagas nilai moral demi mewujudkan keadilan? Penafsiran hukum hakim tak lepas dari pemaknaan atas konsep hukum itu sendiri. Gadamer katakan bahwa Ilmu Hukum adalah sebuah eksemplar hermeneutik in optima forma yang dipublikasikan pada aspek hukum kehidupan bermasyarakat. Dalam mengimplemen-

1 Bagir Manan, Suatu Tinjaun Terhadap Kekuasan Kehakiman Dalam Undang-Undang Nomor 4 Tahun 2004 ( Mahkamah Agung Republik Indonesia 2005) 209. 
tasikan ilmu hukum untuk menyelesaikan suatu masalah hukum, kegiatan interpretasi itu tidak hanya dilakukan terhadap teks yuridis, melainkan juga terhadap kenyataan yang menimbulkan masalah hukum yang bersangkutan. Terbentuknya teks yuridis terjadi dalam kerangka cakrawala pandang pembentuk hukum berkenaan dengan kenyataan hukum yang dianut atau hidup dalam masyarakat. ${ }^{2}$ Dengan demikian pemenuhan nilai-nilai dalam hukum, merupakan suatu proyeksi yang dianut dalam legal hermeneutik yang harus dilakukan hakim. Menggagas cita moral dalam penafsiran hukum hakim sejatinya bertolak dari konsepsi law as interpretation/processes of interpreting, serta pada hukum sebagai nilai di mana dikonsepsikan law as what ought to be in moral or ideal precepts.

\section{PEMBAHASAN}

\section{Hukum Hakim dan Moral}

Kajian tentang moralitas dalam keterhubungannya dengan hukum tak lepas dari pemikiran Lon Luvois Fuller. Fuller menuliskan tentang 'the morality of law dimana Fuller melihat hukum sebagai institusi yang tidak bisa dipisahkan dari moral. Keduanya memiliki hubungan yang niscaya. Hukum selalu mengandung prinsipprinsip nilai-nilai moral. Fuller melalui penyebutan 'inti moralitas hukum' (inner morality of law), kajian hukum memiliki tujuan tertentu untuk mengarahkan subjek hukum tunduk pada aturan sesuai dengan prinsip-prinsip moral hukum (idela fidelity of law). Pengabaian tujuan menurut Fuller akan menjadikan kajian hukum tidak punya arti bagi perbaikan hukum. Bagi Fuller, perbaikan hukum atau reformasi hukum dapat dicapai dengan cara tidak memisahkan hukum dari moralitas.

Berbeda dengan Fuller, H. L. A. Hart berpandangan bahwa tidak ada hubungan mutlak antara hukum dan moralitas dan menganggap bahwa prinsip yang diajukan Fuller bukan sebagai prinsip moral melainkan prosedurprosedur yang dibuat agar hukum bisa berlaku efektif. Hart berpendapat bahwa kajian hukum harus deskriptif tanpa menilai kualitas moral yang dikandungnya. Hart sebagaimana Bentham dan Austin melihat perbaikan hukum dapat dicapai melalui pemisahan hukum dari moralitas. ${ }^{3}$

Hubungan hukum dan moral sejatinya tidak bisa dipisahkan secara tajam. Hukum tidak bisa berjalan dengan tanpa moral, karena akan mengakibatkan hukum mengarah pada pencapaian prosedural semata dan menimbulkan efek hukum yang tidak sesuai rasa keadilan dan mengabaikan prinsip-prinsip moral. Maka, sudah menjadi keniscayaan untuk dielaborasinya cita hukum oleh hukum hakim untuk menjadi materi muatan tujuan hukum itu sendiri dalam putusanputusan hakim.

2 Ilmu hukum menurut Gadamer adalah sebuah eksemplar hermeneutik in optima forma yang dipublikasikan pada aspek kehidupan bermasyarakat. Lihat Paul Scholten, De Structuur Der Rechtswetenschap dalam B. Arief Sidharta (tjm), Struktur Ilmu Hukum (Cet. ke-2, Alumni 2005) 122.

3 Petrus C. K. L. Bello, Hukum \& Moralitas: Tinjauan Filsafat Hukum (Cet. pertama, Erlangga 2012) 8586. 
Paul Scholten dalam Arief Sidharta mengemukakan bahwa:

Tatanan hukum merupakan pengejewantahan cita hukum ke dalam berbagai perangkat aturan hukum positif, lembaga hukum dan proses. Cita hukum adalah gagasan, karsa, cipta, dan pikiran berkenaan dengan hukum yang terdiri atas tiga unsur, yakni keadilan, kehasilgu-naan, dan kepastian hukum. Cita hukum itu diproyeksikan pada proses pengkaidahan perilaku warga masyarakat yang mewujudkan tiga unsur cita hukum tadi. Dalam dinamika kehidupan kemasyarakatan, cita hukum itu akan mempengaruhi dan berfungsi sebagai asas hukum yang mempedomani, norma kritik (kaidah evaluasi), dan faktor yang memotivasi dalam pembentukan, penemuan dan penerapan hukum. Dengan demikian, seyogyanya tata hukum itu merupakan sebuah eksemplar remifikasi cita hukum ke dalam pelbagai asas dan kaidah yang tertata (tersusun) dalam sebuah sistem. Cita hukum bangsa Indonesia berakar dalam Pancasila.'4

Cita hukum Indonesia yang harus diwujudkan oleh hakim tak lepas dari prinsip-prinsip moral sebagaimana terkandung dalam volkgeist atau jiwa bangsa yang merupakan refleksi etika sosial kristalisasi nilai luhur yang diakui secara universal dalam kebajikan manusia/human virtue. Penafsiran hakim terlingkupi oleh entitas hukum yang masuk dalam keseluruhan habitus kehidupan hukum dalam masyarakat. Penafsiran hakim merupakan konstruksi dinamis dalam kehidupan hukum yang berdimensi hukum itu sendiri atau pranata hukum, dan bisa saja berkorelasi pada individu, birokrasi atau lembaga hukum, elemen bermasyarakat dan bernegara yang menjadi lingkup kepentingan dalam suatu putusan atau dampak dari pengambilan putusan hakim. Dalam hal ini, hakim melihat kerangka kepentingan yang lebih luas, menyuarakan aspek materia hakekat sejatinya muatan keadilan substansial dari putusan hakim, dibanding hanya menggagas pada aspek prosedural formal saja. Dalam kerangka membangun penafsiran hukum hakim, maka harus berpondasi pada keadilan, kemanfaatan serta kepastian hukum. Dalam pelbagai teori pembuktian, hakim memutus bukan saja memutus berdasarkan minimum alat bukti yang ada, melainkan juga berpangkal pada hati nurani hakim. Hakim adalah pemegang profesi luhur dari profesi hukum yang memiliki predikat 'yang mulia'.

Hakim sebagai sub sistem dalam sistem peradilan adalah peletak akhir dari suatu perjuangan keadilan yang tergambar melalui putusan-putusannya. Jika sub sistem ini masuk menjadi bagian dari permasalahan yang ditanganinya, maka putusan hakim tersebut tidak akan pernah mendemonstrasikan keadilan, baik keadilan menurut hukum yang diharapkan oleh masyarakat dan negara. Untuk dapat menemukan jalan keluar persoalan yang demikian, maka ada tiga samudra yuridis yang perlu menjadi dasar pertimbangan hukum hakim. Ketiga samudra yuridis tersebut ialah asas legalitas yang melahirkan kepastian hukum (wetmatigheidbeginslen), keadilan hukum (gerechtigkeit), dan kemanfaatan (zweckmatigkeit $=$ dulma-

4 Paul Scholten dalam B. Arief Sidharta (tjm), Op.Cit., 134. 
tigheid. Kemanfaatan ini tertuju kepada addresat keadilan, yaitu masyarakat sekaligus membawa serta filosofisnya suatu aturan hukum yang dipegangnya. ${ }^{5}$ Fungsi hakim bukan sematamata menegakkan hukum, tetapi juga sekaligus menegakkan atau memberikan keadilan bagi para pencari keadilan melalui putusan pengadilan yang berkekuatan hukum tetap. Filsafat hukum sangat diperlukan oleh hakim agar putusannya benar-benar merefleksikan keadilan. Dalam perspektif filsafat hukum, keadilan tersebut dapat didekati, baik dari sisi prosedural maupun substansial. Keadilan prosedural dimaknai sebagai keadilan yang bersumber dari peraturan perundangundangan yang berlaku, sedangkan keadilan substansial diperoleh dengan cara menggali nilai-nilai yang tumbuh dan hidup di dalam masyarakat. Peraturan perundang-undangan memang harus menjadi rujukan hakim dalam pertimbangan hukum dari putusannya. Namun, hakim juga wajib membaca peraturan perundangundangan tersebut dari perspektif filsafat hukum. Filsafat hukum sangat berguna untuk mengembangkan rasa keadilan hakim agar ketika menerapkan dan menafsirkan ketentuan perundangundangan terhadap masalah hukum konkret, ia dapat memenuhi dan menyelami rasa keadilan sosial di dalam masyarakat sebelum memutus perkara yang diajukan kepadanya. ${ }^{6}$ Penggalian kebenaran dalam filsafat hukum melalui kebenaran yang reflektif dan kritis untuk searching for the truth about law dalam hal ini putusan hakim adalah menggambarkan bahwa tugas hakim bukanlah menjadi tukang hukum yang hanya terampil menerapkan bunyi perundang-undangan, namun menjadi pengemban hukum yang dalam memiliki pemikiran dari hasil permenungan tentang keadilan, yang berarti menuntutkan nilai moral untuk menjadi isi putusan.

Perspektif moral pada hukum pada sejatinya menempatkan hukum dalam kerangka menciptakan kemaslahatannya bagi penghormatan martabat manusia. Hukum yang baik adalah hukum yang membawa manusia untuk dihormati harkat dan martabatnya. Hukum hakim yang baik senantiasa akan mengabdi pada nilai moral kemanusiaan itu sendiri. Hukum yang bermoral adalah hukum yang memperadabkan manusia sejalan dengan penghormatan akan harkat dan martabat kemanusiaan itu sendiri.

Untuk mewujudkan tujuan hukum yang sesungguhnya yakni menjadikan hukum yang progresif, tentu mengabdi kepada nilai manusia untuk mewujudkan keadilan di masyarakat dan kebahagiaan bagi warga masyarakatnya, semua metode penafsiran perlu dikerahkan (penafsiran yang luas). Perkembangan ilmu hukum harus melibatkan

5 Kamri Ahmad, 'Kriminalisasi KPK Suatu Tinjauan Hubungan Antara Fakta, Norma, Moral, dan Doktrin Hukum Dalam Pertimbangan Putusan Hakim' (2011) 40 (4) Jurnal Masalah-Masalah Hukum 519, 520.

$6 \quad$ Marihot Janpieter Hutajulu, 'Filsafat Hukum Dalam Putusan Pengadilan/Hakim' (2015) 9 (1) Refleksi Hukum: Jurnal Ilmu Hukum 91, 96. 
ilmu sosiologi hukum, sejarah hukum, dan filsafat hukum. ${ }^{7}$ Seharusnya seorang hakim berfikir dalam proses 'penemuan hukum', agar dapat menghasilkan putusan yang berkualitas dalam setiap sengketa yang dihadapi harus senantiasa mengisi kekosongan hukum itu dengan menggunakan: norma hukum, ilmu hukum, teori hukum, dan filsafat hukum (metode penemuan hukum). ${ }^{8}$ Bertolak dari dibutuhkan kajian komporehensif bagi hakim dalam memutus suatu perkara dengan menggagas nilai moral sebagaimana dikemukakan di atas, maka dapat dikemukakan kesejatian putusan hakim pada hakekatnya bernuansakan kajian filsafat hermeneutic yang berupaya sebagai kajian filsafat etis mengenai hal untuk memahami sesuatu sebagai suatu refleksi kefilsafatan tentang hukum dalam memutus suatu perkara.

Gregory Leyh mengatakan bahwa keputusan-keputusan hukum merupakan buah dari semacam pertimbangan humanistik yang melangkah keluar dari aplikasi metodis aturan-aturan hukum. Mengutip Ronald Beiner, dinyatakan oleh Gregory Leyh, bahwa pertimbangan merupakan bentuk kegiatan mental yang tidak terikat oleh aturan-aturan, tidak tunduk pada spesifikasi tata kerjanya (tidak seperti rasionalitas metodis), dan berlangsung di luar batasan-batasan pemikiran yang digariskan oleh aturan. Tipe kegiatan mental ini diperlukan oleh pengacara atau hakim (penulis: hakim) yang harus menyeimbangkan nilai yang terdapat dalam sebuah kasus. ${ }^{9}$ Dunia peradilan pada hakekatnya adalah berbicara tentang dunia yang penuh nilai dan bukan bebas nilai. Dunia peradilan bukanlah dunia teknis seperti mesin juridis yang menafikan faktor-faktor nilai itu sendiri.

Bertolak dari pemikiran di atas, maka penafsiran hukum hakim merupakan suatu proses mental hakim. Proses penafsiran hakim yang diliputi oleh mental hakim dalam perspektif hukum, keseluruhan yang membentuk cakrawala pandang meliputi kedalaman dan luasan suatu kasus dan hati nuraninya. Oleh karenanya, pembentukan realitas penafsiran hakim merupakan suatu konstruksi yang memuat gambaran mengenai fakta hukum dan fakta sosial yang menjadi faktor pembentuk penafsiran hakim. Dalam perspektif ini, maka penafsiran hakim merupakan perspektif mental activity hakim untuk mensarikan nilai esensi legis dalam putusannya.

\section{Proses Penafsiran Hukum}

Proses penafsiran hukum hakim hakekatnya adalah proses penafsiran hukum hakim yang bermuara pada kebutuhan akan pencarian suatu kebenaran dalam pengambilan putusan.

7 Muhammad Syamsudin, 'Pemaknaan Hakim tentang Korupsi dan Implikasinya Pada Putusan: Kajian Perspektif Hermeneutika Hukum’ (2010) 22 (3) Mimbar Hukum 489, 517.

8 Lintong Oloan Siahaan, 'Peran Hakim Dalam Pembaruan Hukum di Indonesia Hal-Hal yang Harus Diketahui (Proses Berfikir) Hakim Agar Dapat Menghasilkan Putusan yang Berkualitas (2006) 36 (1) Jurnal Hukum dan Pembangunan 27, 43.

9 Hans-Georg Gadamer, Truth and Method diterjemahkan oleh M. Khosim (tjm), Hermeneutika Hukum, Sejarah, Teori dan Praktik (Cet. pertama, Nusa Media 2008) 400. 
Dalam hermeneutika maka proses pencarian kebenaran akan dipengaruhi oleh aktor sosial yang melakukan interpretasi. Hakim sebagai interpreter hukum berada dalam suatu ruang tradisi yang berisi nilai, pandangan, kaidah, pola-pola perilaku, dan sebagainya. Penafsiran hakim sejatinya terjalin dalam suatu proses interaksi dan membentuk pra pemahaman yakni pra sangka yang kemudian membentuk cakrawala pandang tentang interpretandum. Dalam dinamika proses interpretasi, pra pemahaman dan cakrawala pandang mengalami dinamisasi, dan berinteraksi membentuk pemaknaan dari aktor sosial. ${ }^{10}$ Kebebasan hakim merupakan kewenangan penting yang melekat pada individu hakim dimana hakim berfungsi sebagai penerap teks UU ke dalam peristiwa yang konkret, tidak sekedar substantif, tetapi juga memberikan penafsiran yang tepat tentang hukum dalam rangka meluruskan peristiwa hukum yang konkret sehingga hakim dapat bebas memberikan penilaian-penilaian dan penafsiran hukumnya. ${ }^{11}$ Dalam hal ini aktor sosial adalah hakim. Situasi hermeneutik akan dikaji dalam proses interpretasi guna lebih memahami cakrawala pandang dari hakim untuk memberikan putusan yang berkeadilan.
Penafsiran hukum hakim bertolak dari penalaran yang tidak boleh dilakukan sekehendak hati tetapi harus reasonable dan bukan semata logical. ${ }^{12}$ Derida berpendapat bahwa:

'Justice is a continuous search experience that requires fresh and new interpretations and continuous suspension as a feature of "cannot be decided". Justice is always ahead of (beyond) the law, and provokes the law to always approach it. To approach it, it is not enough to just follow the rules, but need to do "fresh judgment". For Derrida, justice plays in legal and opposite areas that are legal, "deconstruction take place in the place in the interval that separates the underconstructibility of justice from the deconstructibility". Justice is at the between legal and non-legal. ${ }^{13}$

Pemikiran Derrida menuntun pertimbangan hakim dengan menggunakan penafsiran hukum yang mampu menguak makna yang tersembunyi dalam sebuah teks perundangundangan, makna yang ada dalam keseluruhan fakta-fakta persidangan. Pencarian makna esensiil yang ada adalah buah dari interpretasi. Oleh karenanya penafsiran hakim dalam filsafat hermenutika adalah penafsiran yang reproduktif.

Dalam perspektif membangun penafsiran hukum hakim, maka paradigma hukum yang dimiliki hakim

10 Paul Scholten dalam B. Arief Sidharta, Op.Cit., 119-121. Lihat Pula Hans-Georg Gadamer, Truth and Method diterjemahkan oleh Ahmad Sahidah (tjm), Kebenaran dan Metode: Pengantar Filsafat Hermeneutika (Cet. pertama, Pustaka Pelajar 2004) 10-48, dan lihat pula E. Sumaryono, Hermeneutik, Sebuah Metode Filsafat (Cet. ke-10, Kanisius 1999) 71-77.

11 Dachran Busthami, 'Kekuasaan Kehakiman Dalam Perspektif Negara Hukum di Indonesia' (2017) 46 (4) Jurnal Masalah-Masalah Hukum 336, 341.

12 Muhammad Musa, 'Penalaran Hakim Menerapkan Ajaran Penyertaan Dalam Putusan Tindak Pidana Korupsi Pada Bank Riau-Kepri' (2017) 46 (4) Jurnal Masalah-Masalah Hukum 349, 351.

13 Widodo Dwi Putro, Kritik Terhadap Paradigma Positivisme Hukum (Genta Publishing 2011) 249; Lihat dalam Lilik Mulyadi 'Interpretation of Judges in Representing The Dynamics of Religion of Indigenous Legal Inheritance of Bali' (2019) 8 (2) Jurnal Hukum dan Peradilan 214, 220-221. 
akan memberi warna interpretasi. Penafsiran hakim selalu akan memiliki muatan nilai-nilai yang mempengaruh sesuai dengan cara pandangnya terhadap hukum. Hermeneutika menjelaskan proses penafsiran hakim dalam konteks yang melingkupi sang interpreter. Interpretasi dikondisikan secara historis, sehingga penafsiran kaidah terwujud dalam bentuk rekonstruksi teks kaidah tersebut melalui praktek, kepentingan-kepentingan, dan problema kontemporer. Kajian hermeneutika merupakan suatu konsekuensi ontologis penggunaan paradigma constructivism. ${ }^{14}$ Di samping itu, perlu kajian aksiologis yang menuntut nilai. Untuk itu diperlukan perspektif wawasan keilmuwan yang bersumber pada pencapaian hukum yang bermuatan moral guna melakukan upaya penjernihan pra pemahaman, cakrawala pandang, dan pemaknaan dari hakim dalam membentuk penafsiran hukum hakim atau mengurangi subjektivitas hakim dengan mengandalkan pada nilai-nilai cita hukum yang ada. Upaya intersubjective meaning akan memperkaya pengalaman mengenai bagaimana penafsiran hukum hakim apabila ada suatu diskrepansi antara penafsiran hukum hakim dan penafsiran dari cita hukum atau penafsiran dari perspektif public face of justice.

Pijakan pertama bagi seorang hakim dalam menafsirkan adalah cara pandang hakim itu sendiri terhadap hukum. Apa yang harus didefinisikan sebagai hukum itu sendiri oleh hakim? Hukum sendiri pada hakekatnya adalah sebuah norma. 15 Hukum bisa dilihat sebagai norma yaitu pernyataanpernyataan yang bersubstansi pengharusan (sollen) yang bisa saja memuat sanksi bagi pelanggaran terhadap norma itu. Hukum juga bisa diartikan sebagai nomos, yaitu pernyataanpernyataan yang bereksistensi sebagai suatu fakta faktual. ${ }^{16}$ Oleh karenanya konsep hukum pada satu sisi adalah peraturan dalam konsep normatif, dan dalam konsep faktual sebagai keteraturan. Hukum dalam kategorinya sebagai norma masih bisa dibedakan dalam norma hukum yang metajuridis seperti halnya keadilan, kepatutan atau asas moral bangsa/volkgeist, dan norma yang positif sebagai akibat pembakuan yakni peraturan perundang-undangan. Hukum dalam manifestasinya yang riil sebagai nomos dapat dibedakan pula, pertama dalam nomos, yang wujudnya adalah keteraturan perilaku lahiriah yang relevan dengan ihwal kehidupan hukum, baik yang mematuhi prosedur formal juridis maupun yang bersifat ekstra juridis berlegitimasi sosio kultural, dan kedua nomos dalam wujudnya sebagai pola ajek dalam ihwal subjek sekolektiva memaknakan realitas yang relevan dalam kehidupan hukum. Hakim sebagai yuris dalam kegiatan adjudikatif akan melewati proses judicial yang terikat pada konsep hukum sebagai

14 Norman K. Denzin and Yvonna S. Lincoln (ed), Hand Book of Quality Research (1 ${ }^{\text {st }}$ edn, Sage Publication 1994) 109-115.

15 Norma merupakan suatu konkretisasi nilai. Norma mengarahkan perilaku, dan juga predisposisi dari perilaku yaitu sikap. Lihat dalam Shidarta, Moralitas Profesi Hukum, Suatu Tawaran Kerangka Berpikir (Cet. pertama, Refika Aditama 2006) 37.

16 Soetandyo Wignjosoebroto, Hukum Konsep dan Metode (Cet. pertama, Setara Press 2013) 18-19. 
norma yang telah mengalami formalisasi atau positivisasi. Namun demikian, sebagai yuris yang irah-irah keputusannya memuat anasir Demi Keadilan Berdasarkan Ketuhanan Yang Maha Esa, dan bukan berdasarkan UU, maka hakim dengan hati nuraninya, mampu mengejawantahkan keadilan berdasarkan Ketuhanan Yang Maha Esa sebagaimana irah-irah putusan pengadilan, dan juga dalam pengalaman manusiawi berpikir tentang penghormatan martabat manusia itu sendiri. Dalam konteks ini, maka hakim akan bergumul dengan persoalan filosofis atau moralis. Keadilan substansial harus mampu dielaborasi hakim untuk diterjemahkan dalam kasus konkret yang diputuskannya. Bahwa hakikat hukum sejatinya adalah persoalan keadilan substansial dan bukan keadilan prosedural semata.

Penafsiran hakim terhadap hukum tergantung pada cara hakim memandang apakah hukum itu sebagai suatu ilmu pasti sebagaimana hukum diartikan sama dengan UU yang tertulis atau hukum dimaknai dalam perspektif ilmu sosial yang selalu memandang bahwa hukum memiliki habitus hukum yag melibatkan tidak hanya peraturan perundang-undangan melainkan stakeholder yang lebih luas yang menjadi sasaran hukum itu. Ilmu hukum sebagai ilmu pasti mendasarkan pada norma dogmatis dengan keajekan atau keteraturan sebagaimana tertuang dalam peraturan dengan tanpa melihat substansi dan ihwal keefektivitasnya. Ilmu hukum sebagai ilmu sosial menggunakan ilmu hukum yang dituntut bukan semata pada kepastian melainkan pada legitimasi filosofis dan legitimasi sosiologis dalam kehidupan faktuil. Ilmu hukum yang dipandang hakim sebagai ilmu sosial selalu mengkaji korelasi setiap hukum yang dikaitkan dengan tuntutan efektivitas dalam realitas dan sebagaimana dinyatakan law as it is in society. Law in abstracto merupakan hukum perundangundangan, sedangkan putusan hakim adalah law in concreto.

Dalam tradisi sistem hukum common law putusan hakim merupakan putusan yang lebih tinggi daripada perundang-undangan, serta memiliki kekuatan untuk ditaati sebagai jurisprudence oleh hakim berikutnya. Oleh karenanya penafsiran hakim dalam sistem hukum common law dipengaruhi oleh putusan hakim terdahulu. Dalam sistem hukum common law, maka kebiasaan hakim terdahulu akan menjadi sumber penafsiran hakim berikutnya. Hakim di Indonesia melakukan positive judgement baik in abstracto maupun in concreto dalam konteks menderivasi dari ketentuan dan norma peraturan perundangan-undangan yang ada dan tidak menekankan pada praktek-praktek jurisprudensi yang ada, mengingat di Indonesia hakim tidak terikat pada putusan hakim yang terdahulu. Dalam negara common law diwujudkan dalam judge made law, tetapi dalam sistem civil law Eropa Kontinental, seperti Indonesia, dihimpun sebagai jurisprudensi. Dalam konteks demikian, hakim di Indonesia sering mengkonsepkan hukum dalam artian ilmu hukum sebagai 'Reine Rechtslehr'.

Dalam upaya membangun model penafsiran hukum hakim yang berpihak pada keadilan, maka penafsiran hakim 
tak lepas dari ide dalam hukum alam. The natural jurisprudence berkutat dalam hukum sebagai bagian sistem moral filosofis dalam penyelenggaraan ide yang ilahi. Pengembangan hukum yang dikemukakan oleh Thomas Aquinas memunculkan perspektif hukum yang tak lepas dari kehidupan yang religious. Dalam perkembangan sejarah hukum, semenjak lahirnya abad Reinaissance, maka pemikiran religious akan lebih mengarah pada pemikiran yang rasional filosofis dalam tataran ideal mengarah pada ius constituendum atau hukum yang seharusnya menurut dunia idea atau hukum yang akan datang atau the law as what ought to be. Dalam perjalanan kehidupan hukum di Eropa Barat, konsep tersebut di atas dipositivisasi kembali sebagai asas-asas moral melalui suatu proses pembentukan produk hukum dalam ius constitutum atau hukum positif atau the law as what it is in the book(s). Dalam pemikiran rasional, maka asas kebenaran moral melalui positivisasi telah dibentuk dan terwujud dalam legitimasi juridis yang ada dalam perundang-undangan. Hukum yang awalnya bernuansa religious dan ditafsirkan oleh kaum agamawan bergeser menjadi pekerjaan profesional oleh kaum jurist.

Dalam konteks faktuil, asas-asas moral tidak hanya ditemui dalam hukum UU, melainkan juga hidup dalam masyarakat yang dikenal dengan 'the living law'. Asas ini memuat kearifan yang bisa saja berbeda atau mungkin sama dengan yang ada secara in abstracto dalam peraturan perundangundangan. Asas moral dalam dunia empirik memuat suatu nilai-nilai moralitas yang memang belum tentu terlegiti- masi oleh lembaga hukum sebagai suatu pranata hukum. Namun, eksistensi asas moral yang tumbuh dari hukum yang hidup dalam masyarakat ini tetap diakui dan didukung oleh masyarakat bahkan sebagai suatu 'the public face of justice', sekalipun mungkin tidak ada kesepadanannya dalam ketentuan yang dibuat oleh kaum jurist. Pasal 5 UU No. 48 Tahun 2009 tentang Kekuasaan Kehakiman (UU Kekuasaan Kehakiman), disebutkan bahwa hakim wajib menggali, mengikuti, dan memahami nilai-nilai hukum dan rasa keadilan yang hidup dalam masyarakat. Dalam penjelasan atas Pasal 5 tersebut dituliskan bahwa ketentuan ini dimaksudkan agar putusan hakim sesuai dengan hukum dan rasa keadilan masyarakat. Jelaslah ada dua frasa yang berbeda dituliskan yakni frasa hukum dan frasa keadilan. Dalam konteks ini tentu ada pemahaman bahwa bisa saja terjadi diskrepansi antara hukum yang dalam konsep legistis dimaknai peraturan perundangundangan atau dengan sebutan lex dan keadilan yang lebih bermuatan ius.

Namun memang, perkembangan moral dalam hukum mengalami suatu pergumulan, manakala hukum yang dibuat jurist sebagai hukum yang berbeda dituliskan yakni frasa hukum dan frasa keadilan. Dalam konteks ini tentu ada pemahaman bahwa bisa saja terjadi diskrepansi antara hukum yang dalam konsep legistis dimaknai peraturan perundang-undangan atau sebutan lex dan keadilan yang lebih bermuatan ius.

Namun memang, perkembangan moral dalam hukum mengalami suatu pergumulan, manakala hukum 
yang dibuat jurist sebagai hukum yang artificial atau buatan mengklaim kebenaran moral hanya berdasarkan legitimasi juridis. Hukum buatan yang dibuat oleh jurist yang dikenal dengan hukum negara lebih mengutamakan aspek kepatuhan dan kedaulatan hukum dalam frame nilai kepastian. Proses inilah yang disebut sebagai suatu proses sekularisasi hukum dan proses memurnikan hukum dari aspek moral yang sesungguhnya, dan digantikan sebagai perintah semata dari pemegang kedaulatan hukum. Pemurnian hukum dari aspek moral ini diikuti oleh Hans Kelsen melalui 'the pure theory of law' ataupun oleh Austin melalui pemikiran 'law is the command of the sovereign'.

Austin terkenal dengan teorinya 'analitical positivism' yang intinya mengatakan bahwa hukum merupakan perintah dari mereka yang memegang kekuasaan tertinggi atau dari yang memegang kedaulatan, sehingga menganggap hukum sebagai suatu sistem yang logis, tetap, dan bersifat tertutup. Jadi, hukum secara tegas dipisahkan dari kaidah (justice) dan hukum tidak didasarkan pada nilai-nilai yang baik atau buruk, melainkan didasarkan pada kekuasaan dari penguasa. ${ }^{17}$

Hukum yang tadinya dimaknai sebagai ius dalam konsep positivistis menjadi sekedar lex. Hukum sebagai norma tertulis, in abstracto, dengan berpedoman pada kepastian hukum yang secluded dan esoterik. Penolakan hukum murni terhadap aspek moral dalam hukum merupakan esensi pemikiran positivistic legistik. Positivisme menghendaki dilepaskannya pemikiran metayuridis dari hukum. Norma hukum haruslah eksis dalam alamnya yang objektif sebagai norma-norma yang positif, ditegaskan sebagai wujud kesepakatan kontraktual yang konkrit antara warga masyarakat dan wakilwakilnya. Hukum tidak lagi mesti dikonsepsi sebagai asas moral metayuridis yang niskala (abstrak) tentang hakikat keadilan, melainkan ius yang telah mengalami positivisasi sebagai lege atau lex. Ajaran positivisme menjadi alat atau sarana yang berperilaku teknis prosedural formal semata. ${ }^{18}$ Paradigma positivisme legisme memandang hukum sebagai gejala tersendiri yang dipandang sebagai closed logical system.

Konsep hukum berikutnya yang membentuk hukum hakim adalah hukum yang terkait sebagai suatu institusi sosial dalam perspektif sosiologis. Dalam konsep ini norma hukum diderivasi dalam wujudnya sebagai bagian dalam keseluruhan kehidupan fakta sosial yang berkorelasi dengan habitus hukum dalam masyarakat. Hukum dimaknai bukan sebagai rule based tetapi dalam 'behaviour based atau pattern of bahaviour. Dalam hal ini hukum adalah sebagai sesuatu yang seharusnya menurut pola-pola perilaku yang ada dalam tataran empiris. Dalam konsep hukum ini, maka sumber hukum bukan saja pada perundang-undangan, tetapi apa yang memang menjadi norma yang diakui dalam masyarakat. Law is not a set of regulations, or law as it is not

17 W. Friedmann, Teori Filsafat Hukum (Cet. pertama, Rajawali 1990) 149-151.

18 Soetandyo Wignjosoebroto Hukum: Paradigma, Metode, dan Dinamika Masalahnya (Cet. pertama, Elsam-Huma Jakarta 2002) 91, 95-96. 
just written in code of norma, but law as a regularities of behavior as it is observed in society. Dalam perspektif hukum, maka hakim akan bisa mempergumulkan antara diskrepansi hukum yang dinormakan dalam peraturan perundang-undangan (as it is written in the book), dengan hukum yang ada faktuil empirik dalam nomos-nya pada masyarakat (as it is observed as pattern legal behavior in society). Di sinilah hakim diminta untuk menggali nilai yang mengacu pada rasa keadilan masyarakat yang tentu berkiblat pada moral.

Dalam fenomena sosial, jelas ada diskrepansi/tension antara konsep hukum dan peraturan. Hukum tidak semata-mata untuk menegakkan peraturan dalam arti status quo perundangundangan semata, tetapi juga memiliki visi untuk menciptakan tatanan hubungan harmonis dalam suatu relasi sosial yang berkeadilan. Ini berbeda dengan konsep peraturan yang lebih menitikberatkan pada suatu penegakan rule/ aturan, dan tanpa melihat dampak dari pengenaan aturan tersebut, apakah berkeadilan atau berkemanfaatan atau justru tidak sama sekali. Ini berarti konsep peraturan lebih ditujukan pada suatu supremacy of law yang menandaskan central behavior control by law yang bebas nilai/value free.

Koreksi terhadap pemikiran bahwa hukum adalah bebas nilai dikemukakan oleh Paul Scholten yang bahwa ilmu tentang hukum adalah juga ilmu tentang peristiwa sejarah (perundangundangan) dan tentang hubungan kemasyarakatan.... 'Kemurnian' ilmu hukum selalu mengandung sesuatu yang tidak murni dari bahannya. Jika hal ini tidak dilakukan, maka ia akan menjadi "makhluk tanpa darah" (bloodless phantom). ${ }^{19}$ Artinya bahwa hukum tidak mungkin akan menjadi murni, karena bahan hukum itu sendiri diambil dari masyarakat yang memiliki norma dan nilai.

Hukum (ius/law) tidaklah sama dengan UU atau peraturan (lex/laws). Bagi penganut positivisme maka hukum disamaartikan dengan peraturan. Tetapi hukum bukanlah sekedar peraturan. Dalam hal ini, pandangan Roscoe Pound dapat menjadi acuan. Menurut Pound:

'Law is a body of ideals, principles and precepts for the adjustment of the relations of human beings and the ordering of their conduct in society. Law seeks to guide decision as laws seek to constrain action. Law is needed to achieve and maintain justice. Laws are needed to keep the peace to maintain order. Law is experience developed by reason and corrected by further experience. Its immediate task is the administration of justice; the attainment of full and justice to all. The task of laws is one of policing, of maintaning surface of order. ${ }^{20}$

Kesalahan dari positivisme menurut Scholten bahwa ia sebagai material hanya melihat UU, peraturanperaturan. Ia melupakan bahwa di belakang bahan-bahan positif ini terdapat sesuatu yang lain, yang juga demikian pentingnya, bahwa hukum adalah bagian dari kehidupan spiritual

\footnotetext{
19 B. Arief Sidharta (tjm), Op.Cit., 12-13.

20 Rouscoe Pound, Law Finding Through Experience and Reason (1 ${ }^{\text {st }}$ edn, Georgia University Press 1960) 1-2.
} 
(rohaniah, kejiwaan) manusia, individual dan dalam kebersamaan. ${ }^{21}$ Dengan demikian, sebagai interpreter of law, maka hakim akan melakukan interpretasi hukum, bukan hanya menjadi sekedar corong perundang-undangan. Inilah sebabnya maka irah-irah yang dituliskan dalam kepala putusan bukanlah 'Demi Keadilan berdasarkan UU', namun bertuliskan 'Demi Keadilan berdasaran Ketuhanan Yang Maha Esa'. Bahkan dituliskan jika irah-irah 'Demi keadilan Berdasarkan Ketuhanan Yang Maha Esa' tidak dicantumkan dalam putusan, maka putusan itu akan berakibat putusan menjadi batal demi hukum, sebagaimana tertuang dalam Pasal 197 ayat (2) KUHAP.

Hukum bagi hakim akan bermakna melalui penafsiran. Dalam konteks ini, hakim akan menafsirkan hukum dalam suatu cakrawala pandang yang mempengaruhi penafsiran hakim. Hukum menjadi sebuah bahasa yang harus diterjemahkan hakim dalam bahasa hukum hakim. Hal ini berarti hakim menjadikan hukum memiliki fakta-fakta simbolik law as it is embedded in individual judge's mind. Maka penting bagi hakim untuk mengintrodusir kaidah moral dalam makna hukum yang dinyatakan dalam keyakinan hakim, dan bersumber dari 'the ideal of law' sebagaimana kepala putusan yang berbunyi 'Demi keadilan berdasarkan Ketuhanan Yang Maha Esa'.

Dalam konteks penegakan hukum, hubungan antara fakta, norma, moral, dan doktrin hukum dalam pertimbangan putusan hakim baik secara sendirisendiri, maupun bersama sangat terkait atau korelatif satu sama lain. Putusan hakim harus merefleksikan komponenkomponen tersebut. Putusan hakim yang dipertanggungjawabkan secara ilmiah adalah yang memenuhi persyaratan utama seperti yang diajarkan oleh Josef Esser, yaitu sistem konsisten dan adil utamanya mewujudkan law and legal reform. Putusan hakim yang tidak mengindahkan moral sesungguhnya gagal dari aspek pertanggungjawaban moral. Sedang putusan hakim yang tidak memuat doktrin hukum maka sesungguhnya putusan tersebut telah kehilangan arah (lose of direction). Dengan demikian, baik fakta hukum, norma, moral maupun doktrin hukum sesungguhnya merupakan instrumen otentik bagi hadirnya putusan hakim yang baik. Instrumen tersebut merupakan "conditio sine qua non" bagi putusan hakim yang meneguhkan rasa keadilan masyarakat (sense of justice). Ditinjau dari perspektif rasionalitas hukum, putusan hakim dan hubungannya dengan fakta, norma, moral, dan doktrin dapat diklasifikasi ke dalam tiga tipe rasionalitas hukum, yaitu rasionalitas formal, rasionalitas substantif, dan rasionalitas refleksif. Masing-masing tipe rasionalitas hukum menggambarkan status dan kedudukan fakta, norma, moral dan doktrin dalam hubungannya dengan putusan hakim. Pola hubungan yang berlangsung saat ini masih didominasi tipe rasionalitas hukum formal. Ke depan dalam rangka 'good court governance' pengembanan hukum praktis hendaknya di arahkan ke tipe rasionalitas refleksif, minimal diupayakan menggeser pola hubungan tersebut dari tipe rasionalitas formal ke

21 Paul Scholten dalam B. Arief Sidharta (tjm), Op.Cit., 18. 
rasionalitas substantif dan pada saatnya ke arah tipe rasionalitas hukum refkleksif. 22

Scholten $^{23}$ menegaskan bahwa hukum ini atau itu harus tidak tergantung pada apa yang dikatakan UU atau yurisprudensi yang lebih tua. Ilmu hukum yang keliru mengenai hal ini tidak menangkap kenyataan dari hukum. Hukum hakim (rechtspraaksrecht, judge made law) adalah hukum yang terbentuk baru, tetapi hukum ini sudah ada. Hukum yang ada adalah hukum yang sedang menjadi (het wordende recht)...24 Satjipto mengatakan bahwa buku asli Scholten berbunyi 'Het rech is er, doch het moet worden gevonden, in de vondst zit het nieuwe' yang berarti 'hukum itu ada, tetapi ia harus diketemukan dalam penemuan itulah terdapat yang baru'.

Pengembanan ilmu hukum adalah kegiatan mempersiapkan putusan hukum yang secara rasional dapat dipertanggungjawabkan, yakni yang dapat ditempatkan dalam kerangka tatanan hukum yang berlaku sebagai salah satu subsistem dari sistem kemasyarakatan bermuatan dan disistematisasi yang mutlak mensyaratkan interpretasi terhadap teks otoritatif itu. ${ }^{25}$ Oleh karenanya jelas bahwa penafsiran hukum hakim bukanlah hanya sekedar membunyikan saja apa yang tertera dalam perundang-undangan, namun hakim dengan filsafat hukumnya akan selalu mencari kebenaran secara reflektif.

Sebagaimana Sampford menyatakan bahwa hukum bekerja dalam suatu konteks masyarakat yang sebenarnya penuh ketidakberaturan, namun dipaksakan dilihat sebagai penuh keteraturan. Samphord menyatakan bahwa teori hukum dapat juga muncul dari apa yang disebut dengan teori 'keos'/ chaos dalam hukum. Teori hukum dibangun dari sesuatu keadaan masyarakat yang disebut sebagai Melle. Realitas masyarakat selalu berada dalam situasi keos yang tidak dapat diprediksi dan tidak sistematis, karena adanya kekuatan-kekuatan yang berbenturan di dalamnya. Hukum hadir dalam konteks masyarakat yang tidak beraturan ini, sehingga basis sosial hukum penuh dengan hubungan asimetris. ${ }^{26}$ Inilah yang harus dikaji dalam proses pemahaman hakim dalam melakukan interpretasi. Oleh karenanya, hakim tidak boleh menjadi corong UU semata, namun mampu untuk merefleksi perundang-undangan itu dengan hati nuraninya yang mempertimbangkan pelbagai aspek termasuk nilai moral, nilai keadilan.

Kelemahan UU memang bukan berarti hilangnya makna pencarian keadilan, namun sebagaimana Yahya Harahap mengutip Taverne 'Geef me goede rechter, goede rechter commissarissen, goede officieren van justitie en

22 H.M. Soerya Respationo dan M. Guntur Hamzah 'Putusan Hakim: Menuju Rasionalitas Hukum Refleksif Dalam Penegakan Hukum (2013) 2 (2) Jurnal Yustisia 101, 107.

23 Satjipto Rahardjo, Imu Hukum (Cet. ke-4, Citra Aditya Bakti 1996) 96.

24 Paul Scholten dalam B. Arief Sidharta (tjm), Op.Cit., 20-21.

25 Ibid., 118.

26 Dalam Steven Vago, Law and Society (5th edn, Prentice Hall 1997) 50 dan lihat pula Charles Sampford, The Disorder of Law, A Critique of Legal Theory (5 $5^{\text {th }}$ edn, Basil Blackwell Inc. 1989) 151, 160, 223-266. Law is unsystematic etc, Sampford dikenal sebagai pencetus the legal melee dalam kandungan social melee. 
goede politie ambtenaren, en ik zal met een slecht wetboek van stafprocessrecht het goede bruken' (bukan rumusan UU yang menjamin kebaikan pelaksanaan hukum acara pidana, tetapi hukum acara pidana yang jelekpun dapat menjadi baik jika pelaksanaan ditangani oleh aparat penegak hukum yang baik).27 Jelaslah bahwa di pundak hakim terletak tanggung jawab moral pula untuk menegakkan keadilan.

\section{Kebebasan Hakim}

Kebebasan hakim merupakan suatu keniscayaan apabila hakim dituntut untuk memutuskan sesuai dengan rasa keadilan. Dalam penegakan etika profesi hakim, maka dibutuhkan suatu kebebasan yang bertanggung jawab. Penghormatan terhadap kebebasan hakim ini adalah syarat mutlak dalam negara hukum yang menjamin peradilan yang bebas atau peradilan yang mandiri.

Dalam pertimbangan UU Kekuasaan Kehakiman ditegaskan bahwa kekuasaan kehakiman adalah kekuasaan yang merdeka untuk menyelenggarakan peradilan guna menegakkan hukum dan keadilan. Makna kebebasan peradilan bisa diselaraskan dengan makna kemandirian peradilan. Dimaksudkan dengan kemandirian peradilan adalah bebas dari campur tangan pihak luar dan bebas dari segala bentuk tekanan baik fisik maupun psikis.
Kebebasan hakim sejalan dengan karakteristik negara demokrasi dengan mewujudkan a freedom and partial judiciary.

Lingkaran pandangan kebebasan menurut Franz Magnis Suseno berkaitan dengan suara hati. Suara hati merupakan filter terakhir yang dimiliki manusia dalam menilai setiap sikap dan tindakannya. Suara hati akan membentuk sebuah penilaian yang otonom atas sikap dan tindakan kita berhadapan dengan tuntutan masyarakat, moral spontan dan ideologinya. Suara hati adalah kesadaran moral dalam situasi konkret. Suara hati adalah pusat kemandirian manusia. Manusia secara moral hanyalah berkewajiban untuk menaati segala bentuk perintah, larangan dan kebiasaan sejauh sesuai dengan suara hatinya. Suara hati merupakan pangkal otonomi manusia, pusat kemandiriannya. Suara hati adalah piece de resistence, unsur perlawanan yang akan mengganggu kerukunan dengan pihak yang tidak benar. Suara hati membuat manusia menjadi sadar bahwa manusia selalu berhak untuk mengambil sikap sendiri karena tuntutan suara hati bersifat mutlak. Suara hati mutlak hanyalah tuntutan untuk tidak pernah menyeleweng dari apa yang kita sadari sebagai kewajiban kita. Tuntutan untuk selalu bertindak dengan baik jujur, wajar dan

27 M. Yahya Harahap, Pembahasan Permasalahan dan Penerapan KUHAP: Penyidikan dan Penuntutan (Ed. ke-2, Cet. pertama, Sinar Grafika 2002) 6. Lihat pula dalam Soegeng Hardiyanto, 'Hukum Moral Dalam Sanubariku' Sebuah Tuturan Ulang Etika Kewajiban Kategoris, dalam buku Merenung Pembangunan, Punjung Tulis 70 Tahun Liek Wilardjo (Cet. pertama, Fakultas Teknik Elektro dan Program Pascasarjana Studi Pembangunan Universitas Kristen Satya Wacana 2009) 107 bahwa manusia ternyata tidak hanya makhluk tahuan (erkennendes wesen), yang membuat akal budinya suatu penggunan teoretis, tetapi juga sekaligus makhluk lakuan (handelndes wesen) yang membuat akal budinya suatu penggunaan praktis. Semboyannya: Handle Moralisch! Berlakuanlah secara moral! 
adil.28

Suara hati yang dikemukakan oleh Franz Magnis Suseno apabila dipertautkan dengan sosok hakim, maka akan selaras dengan tuntutan hakim untuk memutus tidak hanya dengan memperhatikan pembuktian sebagaimana yang menjadi syarat untuk memutus suatu perkara, namun ditegaskan bahwa hakim juga harus memutus dengan keyakinan hakim. Keyakinan hakim ini tentu adalah dimaksudkan sebagai tuntunan suara hati yang mengawal hakim untuk tidak keluar dari kaidahkaidah moral keadilan yang seharusnya dijewantahkan dalam putusan.

Kebebasan hakim atau independensi hakim dikemukakan pula dalam konferensi Internasional Commission of Jurist bahwa 'independence does not mean that the judge is entitled to act in an arbitary manner'. Batasan dalam kebebasan hakim adalah terutama aturan-aturan hukum itu sendiri. Kekuasaan kehakiman dalam melakukan independensinya tidak melanggar hukum dan tidak bertindak sewenangwenang. Hakim tidak dapat bertindak contra legem. Kebebasan hakim atau independency of judiciary harus selaras dengan akuntabilitas peradilan/judicial accountability.

Dalam penafsiran hakim untuk memutus perkara yang diperhadapkan padanya secara filosofis hakim bukan saja bertindak untuk menerapkan hukum (rechtstoespassing), tetapi juga harus menemukan hukum (rechsvinding), dan membentuk/ menciptakan hukum (rechtsschepping). Oleh karenanya menjadi persoalan apabila dalam penemuan hukum oleh hakim, bolehkah hakim menyimpangi UU. Bila dikaitkan dengan ajaran klasik bahwa memang betul hakim itu corong UU, maka hal tersebut tidak diperbolehkan. Namun, dalam aliran Begriffsjurisprudentz maupun reaksinya dalam aliran Interessenjurisprudenz hakim memiliki kebebasan untuk melakukan penemuan hukum, karena hakim tidak hanya membunyikan saja peraturan itu, tetapi dapat menafsirkan yang tersirat dalam UU atau esensia legis atau spirit dari peraturan tersebut dengan melakukan penghalusan hukum dan mengkaitkannya dengan kepatutan, kepentingan moral, dan rasa keadilan masyarakat antara lain dengan menggali nilai-nilai keadilan yang hidup dalam masyarakat. Dengan demikian, hakim dalam kebebasannya tidak hanya memandang dalam memutus suatu perkara sebagai suatu hal yang formil logis dalam pekerjaan teknis juridis, melainkan melihat tujuan atau ide dasar untuk menegakkan nilainilai moral berkeadilan dalam memutus perkara yang diperhadapkan padanya. Oleh karenanya kebebasan hakim tetaplah dalam frame derivasi dari asasasas hukum yang menuntut keadilan, kepastian dan kemanfaatan. Namun, berarti pula bahwa bila peraturan yang ada sudah tidak sesuai lagi dengan nilai moral, nilai keadilan untuk menjunjung harkat dan martabat manusia, dan tidak sesuai dengan perkembangan hak asasi manusia yang beradab, maka hakim harus berani untuk memutus sesuai hati nuraninya dengan menggagas nilai moral dalam putusannya.

Dalam wacana akedemik maupun

28 Franz Magnis Suseno, Etika Dasar Masalah-Masalah Pokok Filsafat Moral (Cet. pertama, Pustaka Filsafat 1987) 53-57. 
politik hukum dikenal fungsi hakim sebagai pembaru hukum, dalam fungsinya yang demikian hakim bukan sekedar menerapkan aturan tapi lebih menukik lagi menemukan dan menciptakan hukum. Keyakinan hakim adalah sebuah ruang yang harus dibangun, dikembangkan, dan dilaksanakan sebagai ornamen ilmu dan agama dalam upaya pencari keadilan substantif. Penegakkan etika dan profesi hukum hakim, sebagai profesi luhur atau yang mulia (officium nabile) harus mempunyai kemampuan teknis/profesionalisme (technical aspect). Penegakan etika profesi hukum hakim juga harus dilandasi sukacita hukum Pancasila (ground norm) dimana nilai-nilai Ketuhanan Yang Maha Esa menjadi sebuah konsepsi dasar filosofis di setiap jati diri hakim itu sendiri, dimana juga konsep keadilan sosial dalam Pancasila harus di akselerasikan dalam bentuk keputusan yang adil (keadilan substantif). ${ }^{29}$ Melalui kehormatan dan keluhuran martabat hakim, kekuasaan kehakiman yang merdeka dan bersifat imparsial (independent and impartial judiciary) yang diimbangi oleh prinsip akuntabilitas kekuasaan kehakiman, baik dari segi hukum maupun segi etika diharapkan dapat diwujudkan. ${ }^{30}$

Oleh karenanya jelas bahwa dalam proses penafsiran hukum, hakim sebagai interpreter bukanlah hanya sekedar menerapkan peraturan perundangundangan, namun hakim diharapkan sebagai the last resort dari keadilan melalui penafsiran hukum yang bercita moral. Filsafat hermeneutika memberikan suatu pencerahan bagi hakim untuk menyelaraskan kebebasan hakim guna lebih memberikan pemahaman dan merefleksi teks hukum selalu pada konteks dan kontektualisasinya dengan pemikiran yang 'openmindedness' terhadap nilai moral untuk menambah bobot putusan hakim yang mengarah pada keadilan berdasarkan Ketuhanan Yang Maha Esa. Pertimbangan moral filosofis yang merefleksikan nilai keadilan akan mencitrakan hakim yang mengabdi pada nilai kemanusiaan itu sendiri. Profesi hakim adalah profesi luhur yang menjadi benteng keadilan.

Oleh karenanya, penafsiran hukum hakim bukanlah berada dalam suatu kajian bebas nilai, melainkan hakim dituntut untuk memperjuangkan nilai-nilai itu sendiri dan bukan hanya semata berkutat pada corong UU, namun hakim harus bisa menggali kedalaman nilai-nilai moral untuk memutuskan dengan penuh keadilan.

\section{PENUTUP}

Penafsiran hakim merupakan kajian hakim terhadap fakta-fakta kebenaran yang muncul, sehingga hakim dengan pengetahuan dan keyakinan sesuai hati nuraninya menjamin kebenaran akan putusannya. Menarik dalam perspektif searching for the truth bagi hakim adalah

29 Ery Setyanegara, 'Kebebasan Hakim Memutus Perkara Dalam Konteks Pancasila (Ditinjau dari Keadilan Substantif)' (2014) 44 (4) Jurnal Hukum dan Pembangunan 460, 492 <http://jhp.ui.ac.id/ index.php/home/article/view/31> diakses tanggal 20 September 2019.

30 Eman Suparman 'Menolak Mafia Peradilan: Menjaga Integritas Hakim-Menyelaraskan Perbuatan dan Nuraninya' (2017) 47 (1) Jurnal Hukum dan Pembangunan 61, 69 <http://jhp.ui.ac.id/index. php/home/article/view/135> diakses 20 September 2019. 
bahwa pengambilan keputusan hakim merupakan elaborasi cita moral berupa norma keadilan menuju pada the ideal of law. Inilah tugas hakim dalam memberikan penafsiran atas hukum dan fakta hukum dalam berkelindan antara teks, konteks, dan kontekstualisasi demi pencapaian 'the searching for the truth about law'.

Dalam melakukan penafsiran hukum, hakim tidak semata-mata menafsirkan dari aspek legalitas formal berdasarkan bunyi teksnya semata, namun hakim harus menggali lebih dalam mengenai muatan nilai kebenaran dan keadilan, dengan mengakomodasi pertimbangan moral sesuai dengan hati nuraninya.

\section{DAFTAR BACAAN}

\section{Buku}

Bello Petrus C. K. L, Hukum \& Moralitas: Tinjauan Filsafat Hukum (Cet. pertama, Erlangga 2012 ).

K. Denzin N dan S. Lincoln Y, (Ed), Hand Book of Quality Research (1st edn, Sage Publication 1994).

Friedmann W, Teori dan Filsafat Hukum (Cet. pertama, Rajawali 1990).

Harahap M. Y, Pembahasan Permasalahan dan Penerapan KUHAP: Penyidikan dan Penuntutan (Ed. ke-2, Cet. pertama, Sinar Grafika 2002).

Hardiyanto S, 'Hukum Moral Dalam Sanubariku' Sebuah Tuturan Ulang Etika Kewajiban Kategoris, dalam buku Merenung Pembangunan, Punjung Tulis 70 Tahun Liek Wilardjo (Cet. pertama, Fakultas Teknik
Elektro dan Program Pascasarjana Studi Pembangunan Universitas Kristen Satya Wacana Salatiga 2009).

Manan B, Suatu Tinjaun Terhadap Kekuasan Kehakiman Dalam Undang-Undang Nomor 4 Tahun 2004 ( Mahkamah Agung Republik Indonesia 2005).

Pound R, Law Finding Through Experience and Reason (1 ${ }^{\text {st }}$ edn, Georgia University Press 1960).

Putro Widodo D, Kritik Terhadap Paradigma Positivisme Hukum (Genta Publishing 2011).

Rahardjo S, Ilmu Hukum (Cet. ke-4, Citra Aditya Bakti 1996).

Sampford C, The Disorder of Law, A Critique of Legal Theory (5th edn, Basil Blackwell Inc 1989).

Shidarta B. A, Moralitas Profesi Hukum, Suatu Tawaran Kerangka Berpikir (Cet. pertama, Refika Aditama 2006).

Sumaryono E, Hermeneutik, Sebuah Metode Filsafat (Cet. ke-10, Kanisius 1999).

Suseno Franz M, 'Etika Dasar MasalahMasalah Pokok Filsafat Moral' (Cet. pertama, Pustaka Filsafat 1987).

Vago S, Law and Society $\left(5^{\text {th }}\right.$ edn, Prentice Hall 1997).

Wignjosoebroto S, Hukum Konsep dan Metode (Cet. pertama, Setara Press 2013).

Hukum: Paradigma, Metode, dan Dinamika Masalahnya (Cet. pertama, Elsam-Huma Jakarta 2002). 


\section{Buku Terjemahan}

M. Khosim (tjm), Hermeneutika Hukum, Sejarah, Teori dan Praktik (Cet. pertama, Nusa Media 2008).

Sahidah A (tjm), Kebenaran dan Metode: Pengantar Filsafat Hermeneutika (Cet. pertama, Pustaka Pelajar 2004).

Scholten P, De Structuur Der Rechtswetenschap dalam Sidharta B. A (tjm), Struktur Imu Hukum (Cet. ke-2, Alumni 2005).

\section{Artikel Jurnal}

Ahmad K, 'Kriminalisasi KPK Suatu Tinjauan Hubungan Antara Fakta, Norma, Moral, dan Doktrin Hukum Dalam Pertimbangan Putusan Hakim' (2011) $40 \quad$ (4) Jurnal Masalah-Masalah Hukum.

Busthami D, 'Kekuasaan Kehakiman Dalam Perspektif Negara Hukum di Indonesia' (2017) 46 (4) Jurnal Masalah-Masalah Hukum.

Hutajulu Marihot J, 'Filsafat Hukum Dalam Putusan Pengadilan/Hakim (2015) 9 (1) Refleksi Hukum: Jurnal Ilmu Hukum.

Mulyadi L, 'Interpretation of Judges in Representing The Dynamics of Religion of Indigenous Legal Inheritance of Bali' (2019) 8 (2) Jurnal Hukum dan Peradilan.

Musa M, 'Penalaran Hakim Menerapkan Ajaran Penyertaan Dalam Putusan Tindak Pidana Korupsi Pada Bank Riau-Kepri' (2017) 46 (4) Jurnal MasalahMasalah Hukum.
Respationo H. M. S, dan Hamzah M. G, 'Putusan Hakim: Menuju Rasionalitas Hukum Refleksif Dalam Penegakan Hukum (2013) 2 (2) Jurnal Yustisia.

Setyanegara E, 'Kebebasan Hakim Memutus Perkara Dalam Konteks Pancasila (Ditinjau dari Keadilan Substantif)' (2014) 44 (4) Jurnal Hukum dan Pembangunan.

Siahaan Lintong O, 'Peran Hakim Dalam Pembaruan Hukum di Indonesia Hal-hal yang Harus Diketahui (Proses Berfikir) Hakim Agar Dapat Menghasilkan Putusan yang Berkualitas' (2006) 36 (1) Jurnal Hukum dan Pembangunan.

Suparman E, 'Menolak Mafia Peradilan: Menjaga Integritas Hakim-Menyelaraskan Perbuatan dan Nuraninya' (2017) 47 (1) Jurnal Hukum dan Pembangunan.

Syamsudin M, 'Pemaknaan Hakim tentang Korupsi dan Implikasinya Pada Putusan: Kajian Perspektif Hermeneutika Hukum' (2010) 22 (3) Mimbar Hukum.

\section{Peraturan Perundang-Undangan}

Undang-Undang Nomor 48 Tahun 2009 tentang Kekuasaan Kehakiman. 
